\title{
Pengaruh Store Atmosphere dan Keragaman Produk Terhadap Kepuasan Pelanggan: Studi Pada Pelanggan Coffee Shop Rustic Market Surabaya
}

\author{
Febila Kusuma Wardhani, Renny Dwijayanti \\ Universitas Negeri Surabaya, Surabaya, Indonesia \\ Email authors: wiwin.17080314024@mhs.unesa.ac.id/triesnindapahlevi@unesa.ac.id
}

\begin{abstract}
ABSTRAK
Penelitian ini bertujuan untuk mengetahui pengaruh store atmospheredan keragaman produk terhadap kepuasan pelanggan di Coffee shop Rustic Market Surabaya. Jenis penelitian berikut yaitu penelitian kuantitatif dengan teknik penentuan sampel yakni dengan purposive sampling. Teknik pengumpulan data melalui penyebaran kuesioner. Populasi dalam penelitian berikut yakni konsumen yang sudah melakukan pembelian di Coffee shop Rustic Market Surabaya minimal satu kali, dan sampel berjumlah 100 responden.Teknik analisis yang digunakan yakni berupa regresi linear berganda dengan bantuan software SPSS 25. Hasil dari penelitian ini menyatakan bahwa variabel store atmosphereberpengaruh positif dan signifikan terhadap kepuasan pelanggan, variabel keragaman produk berpengaruh positif terhadap kepuasan pelanggan. Sedangkan store atmosphere $\left(\mathrm{X}_{1}\right)$ dan keragaman produk $\left(\mathrm{X}_{2}\right)$ secara simultan berpengaruh positif terhadap kepuasan pelanggan (Y) di Coffee shop Rustic Market Surabaya dengan kontribusi persentase sebesar 58\% sedangkan terdapat sisa sebesar $42 \%$ dipengaruhi oleh faktor lainnya.
\end{abstract}

Kata Kunci : Store Atmosphere, Keragaman Produk, Kepuasan Pelanggan

\section{PENDAHULUAN}

Seiring perkembangan jaman dan pertumbuhan bisnis di Kota Surabaya pada era milenial saat ini semakin beragam bisnis pada sektor kuliner. Hal ini ditunjang dengan maraknya pengusaha kuliner yang mengembangkan bisnisnya dengan mendirikan cafe yang lebih kreatif dan modern. Kini banyak cafe yang hadir dengan lebih menarik dan memiliki diferensiasi untuk meningkatkan daya saingnya, tidak hanya itu kini kedai kopi atau kerang disebut coffee shop atau cafe tidak hanya sebatas tempat untuk meminum kopi sambil bersantai, berbincang bincang dan bertemu rekan saja, tetapi cafe saat ini juga menjadi tempat pengunjung untuk berswafoto dirinya atau makanan dan minuman yang disajikan. Saat ini di Surabaya tidak sedikit cafe yang mempunyai suasana toko seperti desain ruang eksterior dan interior yang unik dan menarik sebagai daya tarik para pelanggan yang berkunjung ke cafe tersebut. Selain suasana toko yang menjadikan konsumen untuk tertarik datang yakni keragaman produk, karena dengan adanya keragaman produk diharapkan dapat menjaring dan menggaet konsumen lebih banyak lagi dengan berusaha memberikan berbagai variasi produk dan suasana cafe yang menarik dan nyaman dalam cafe tersebut yang dimana mengharapkan konsumen dapat merasa puas, jika konsumen merasa puas dengan fasilitas dan suasana maka besar harapan merekauntukkembali melakukan pembelian ulang serta tidak menutup kemungkinan konsumen dapat menjadi pelanggan tetap.

Salah satu pendukung daripada cafe yakni suasana toko atau store atmosphere, yang dimana suasana cafe diciptakan agar konsumen dapat merasa nyaman akan sesuatu yang berbeda di setiap sudutnya(Sari, 2020).Dalam suasana cafe, diciptakan dengan desain interior dan eksterior, suasana yang tenang, alunan musik, pencahayaan, dan segala sesuatu yang pada akhirnya menciptakan perasaan emosional nyaman yang dialami oleh konsumen. 
Menurut (Novendra H et al., 2019) mengemukakan bahwa suasana toko merupakan ciri khas fisik dan merupakan hal utama dalam setiap mendirikan bisnis ritel, fungsinya agar terciptanya atmosfir yang nyaman bagi pelanggan dan memberikan rasa kepada konsumen untuk bisa berlama-lama di cafe serta secara tidak langsung dapat merangsang konsumen untuk melakukan sebuah pembelian. Strategi yang mempengaruhi efek emosional konsumen agar dapat melakukan sebuah pembelian yakni suasana toko, maka dari itu store atmosphere dinilai sebagai faktor utama dalam memunculkan suatu kepuasan pada konsumen.

Adapun faktor penting lainnya dalam menarik perhatian dan emosional konsumen agar dapat mewujudkan kebutuhan konsumen adalah terdapat berbagai keragaman produk atau menu dalam cafe. Menu atau produk yakni sesuatu yang pada umumnya ada pada bisnis ritel guna dikonsumsi, dikenakan dan dimilikitujuannya untuk memuaskan keinginan dan kebutuhan konsumen(Wuyanti \& Mulyaningsih, 2018). Keragaman produk merupakan berbagai varian produk atau menu yang menyangkut luas, kualitas produk dan kedalaman yang ditawarkan oleh pelaku usaha serta tersedianya produk tersebut pada setiaptoko (Safitri et al., 2017).Cafeyang memiliki keragaman menu yang luas dapat dikatakan memiliki beragam ketersediaan produk yang dapat menimbulkan banyak pilihan dalam proses tindakan pembelian konsumen. Maka semakin beragam menu atau produk yang disediakan oleh karena itu konsumen merasa puas.

Bisnis kuliner saat ini berkembang pesat, khususnya pada bidang cafe di Kota Surabaya yang kini banyak diminati oleh kaum muda yang dimana menunjukkan bahwa semakin banyaknya cafe yang memiliki cita rasa kuliner yang hits dan juga terdapat spot foto instagrammable dalam cafe tersebut. Salah satunya coffee shop Rustic Market. Rustic Market adalah salah satu tempat cafe yang dapat disinggahi untuk nongkrong dan bersantai di Kota Surabaya. Rustic Market terletak di Jl. Golf 1 Surabaya, Gunung sari, Dukuh pakis, Surabaya. Jam buka kafe ini mulai dari 10.00 hingga 21.00. Dengan fasilitas yang lengkap, nyaman dan memiliki atmosfer cafe yang unik dan suasana outdoor yang sejuk memberikan daya tarik bagi para konsumen. Dilihat dari peluang yang ada tersebut, salah satu cafe yang berada di Surabaya ini terbilang masih baru. Rustic Market ini awal berdiri pada tahun 2015 yang merupakan sebuah decoration creative furniture kemudian berkembang menjadi sebuah tempat rental venue wedding yang eksis dengan nama Barn Event Hire berdiri pada tahun 2017 hingga pelaku usaha berpikir mengembangkan tempat ini menjadi sebuah coffee shop pada tahun 2019, cafe ini memiliki konsep yang dapat dikatakan bernuansa alam pedesaan menjadikan suasana cafe asri dan sejuk. Rustic Market juga menyediakan berbagai macam variasi menu, dimana cafe ini mengambil konsep menu Western yang menjual beragam menu dengan rentang hargadari Rp 10.000 sampaiRp 65.000. Rustic Market juga menjual menu kekinian seperti pizza dan ice cream gelato. Menu yang disajikan Rustic Market pun beragam, mulai dari sajian spaghetti, olahan ayam \& daging sapi, kentang goreng, toast, pisang krispi, burger, pancake, rice bowl dan beragam minuman kopi, non coffee olahan susu dan soda serta adanya berbagai fasilitas free wifi, spotfoto instagrammable dan terdapat penampakan hewan rusa yang menambah suasana hidup asri.

Menurut(Novendra $\mathrm{H}$ et al., 2019)kepuasan pelanggan merupakan penilaian atau persepsi terhadap suatu jasa atau produk itu sendiri, yang memberikan rasa senang dimana untuk memenuhi kebutuhan konsumsi konsumen yang diciptakan melalui kualitas, layanan dan nilai. Maka dalam meningkatkan persaingannya ini, Rustic Market harus mampu mempertahankan atau bahkan meningkatkan kepuasan konsumennya.Terdapat berbagai faktor yang dapat menjadi stimulus terwujudnya kepuasan ini, antara lainstore atmosphere dan keragaman produk. Maka dari itu, diperlukan studi yang mengidentifikasi apakah terdapat pengaruh variabel store atmosphere dan keragaman produk terhadap kepuasan pelanggan di Coffee shop Rustic Market Surabaya. 
Hasil penelitian terdahulu yang dilakukan oleh (Rofi'ah, 2020) menunjukkan adanya pengaruh positif dan signifikan pada variabel store atmosphere terhadap kepuasan pelanggan. Selaras dengan penelitian (Safitri et al., 2017) menjelaskan adanya pengaruh signifikan variabel keragaman produk terhadap kepuasan pelanggan. Namun hal yang bertolak belakang ditunjukkan oleh penelitian (Putri et al., 2014) membuktikan pengaruh negatif serta tidak adanya signifikan pada variabel store atmosphere terhadap kepuasan pelanggan. Berkaitan dengan pemaparan tersebut maka peneliti melakukan penelitian yang memiliki judul "Pengaruh Store Atmosphere dan Keragaman Produk Terhadap Kepuasan Pelanggan di Coffee Shop Rustic Market Surabaya."

\section{H1: Store Atmosphere Berpengaruh Terhadap Kepuasan Pelanggan di Rustic Market Surabaya}

Menurut(Purwadi et al., 2020)suasana toko atmosfir mengacu pada apa saja ciri-ciri fisik toko yang digunakan untuk mengembangkan image atau citra dan menarik perhatian konsumen, artinya atmosfir cafe merupakan ciri fisik yang pada umumnya digunakan dalam membangun impresi, loyalitas dan menarik konsumen. Suasana toko yakni desain lingkungan atau ciri khas toko dari perpaduan kombinasi antara lain komunikasi visual, pencahayaan, musik, warna serta aroma yang dapat merangsang persepsi dan tanggapan emosional konsumenhingga pada akhirnya bertujuan mempengaruhi kepuasan pelanggan saat di cafe tersebut. Yang dimana suasana cafe melalui indikator tersebut dapat menciptakan respon emosional positif, persepsi pelanggan jadi memiliki rasa puas.

Store atmosphere pada penelitian ini diberi batasan yakni layout, aroma, suara, tekstur dan desain ruangan cafe. Indikator kuesioner dugunakan untuk mengukur variabel store atmosphere mencakup layout, aroma, suara, tekstur dan desain ruangan yang ada di Coffee shop Rustic Market Surabaya.

Berdasarteori diatas dan didukung penelitian yang dilaksanakan oleh beberapa peneliti antaralain (Rofi'ah, 2020)menunjukkan adanya pengaruh positif dan signifikan pada variabel store atmosphere terhadap kepuasan pelanggan. Penelitian yang dilaksanakan oleh (Hidayat, 2020) membuktikan store atmosphere memiliki pengaruh signifikan. Hasil kajian dari penelitian yang telah dilaksanakan oleh beberapa peneliti dapat dikatakan bahwa variabel store atmosphere berpengaruh terhadap kepuasan pelanggan.

\section{$\mathrm{H}_{2}$ : Keragaman Produk Berpengaruh Terhadap Kepuasan Pelanggan di Rustic Market Surabaya}

Keragaman produk merupakanproduk-produk yang diciptakan guna untuk memenuhi serta melengkapi kebutuhan dan keinginan konsumen, sebab denganmemiliki beragam perbedaan tersebut, perlu adanya keragaman produk agar selera, harapan dan keinginan pelanggan dapat terpenuhi oleh menu atau produk yang ditawarkan kepada konsumen. Berdasarkan(Rohmawati, 2018)Keragaman produk adalah sesuatu mengenai variasi atau keragaman dari setiap produk serta mutu produk tersebut, selain itu keragaman produk ditunjukkan melalui dengan banyaknya pilihan menu yang tersedia, oleh karena itu dapat terpenuhinya kebutuhan pun lebih besar sehingga memberikan dampak kepadakonsumenagar tidak perlu menghabiskan waktu dan tenaga untuk mencari produk yang diinginkan di tempat lain.

Cafe biasanya menyajikan makanan dan minuman ringan tanpa adanya keragaman produk, namun dengan seiring inovasi yang kian berkembang, pengusaha perlu menciptakan keragaman produk kopi dan makanan yang akan ditawarkan kepada pelanggan. Menurut(Safitri et al., 2017) memaparkan bahwa keragaman produk adalah kelengkapan 
produk atau menu yang ditawarkan serta ketersediaan produk atau menu tersebut guna memberikan persepsi positif pelanggan merasa puas.

Keragaman Produk pada penelitian ini diberi batasan yaitu kelengkapan dalam variasi produk yang tersedia, keragaman produk yang ditawarkan memilikikualitas produk yang ditawarkan serta ketersediaan berbagai pilihan menu makanan dan minuman yang memiliki beragam rasa yang berbeda. Indikator kuesioner yang digunakan dengan tujuan agar dapat mengukur variabel keragaman produk mencakup kelengkapan variasi produk yang tersedia, keragaman produk yang ditawarkan memiliki beragam rasa yang berbeda, kualitas produk serta ketersediaan berbagai pilihan menu makanan dan minuman di Coffee shop Rustic Market Surabaya.

Berdasar teori diatas dan didukung penelitian yang dilaksanakan oleh beberapa peneliti antara lain (Safitri et al., 2017) menunjukkan keragaman produk adanyapengaruh positif dan signifikan terhadap kepuasan pelanggan. Penelitian yang dilaksanakan oleh (Nainggolan et al., 2016) membuktikan bahwa adanya pengaruh positif keragaman produk terhadap kepuasan pelanggan. Dari beberapa hasil kajian penelitian yang telah dilaksanakan oleh beberapa peneliti dapat dikatakan bahwa variabel keragaman produk berpengaruh terhadap kepuasan pelanggan.

\section{$\mathrm{H}_{3}$ : Store Atmosphere dan Keragaman Produk Berpengaruh Terhadap Kepuasan Pelanggan di Rustic Market Surabaya}

Menurut (Wuyanti \& Mulyaningsih, 2018) memaparkan store atmosphere adalah kombinasi dari berbagai hal yang memberikan sifat emosional yang dimana dapat memberikan pengaruhemosi pelanggan hingga menstimuli untuk meningkatkan atau mengurangi belanja. Suasana toko berkaitan dengan bagaimana pengusaha dapat memanipulasi desain ruangan, lingkungan, interior, eksterior, tata letak layout, tekstur dinding, bentuk, aroma, warna dan suara yang dirasakan oleh pelanggan yang dirangkum jadi satu memiliki tujuan untuk memberikan pengaruh kepada pelanggan. Keragaman produk yakni berbagai variasi produk dan kelengkapan pada produk, antara lain kualitas, merek, ukuran serta ketersediaan produk tersebut pada toko. Menurut(Arinda et al., 2018) pelanggan cenderung memilih tempat atau suasana yang dapat menyajikan keragaman menu produk lengkapartinyaberhubungan dengan ketersediaan produk dan variasi menu dalam porsi jumlah yang tepat dan penempatan lokasi yang baik. Berdasarkan (Rofi'ah, 2020) pada variabel store atmosphere memiliki pengaruh yang signifikan terhadap kepuasan pelanggan dan menurut (Safitri et al., 2017) keragaman produk mempengaruhi kepuasan pelanggan.

Berdasar pemaparan di atas, dapat dipahami bahwasanyastore atmosphere dan keragaman produk saling mempengaruhi kepuasan pelanggan. Variabel - variabel tersebut mampu membentuk sebuah kepuasan pada pelanggan.

\section{METODE PENELITIAN}

Pada penelitian berikut peneliti menggunakan metode penelitianyakni jenis penelitian kuantitatif agar dapat mengukur seberapa jauh pengaruh antar variabel. Pada penelitian terdapat variabel yang mencakupdua variabel yakni variabel independen meliputi Store Atmosphere dan keragaman produk. Variabel dependen meliputi kepuasan pelanggan.

Dalam menentukan jumlah sampel penelitian dari sebuah populasi, penelitian ini menggunakan teknik slovin, yakni:

$$
n=\frac{N}{1+N e^{2}}
$$


Adapun populasi yang digunakan pada penelitian berikut merupakanjumlah pelangganyang pernah melakukan tindakan pembelian di Rustic Market Surabaya dalam dua bulan terakhirdengan total 5000pelanggan.Maka diketahui populasi pada penelitian ini berjumlah 5000 pelanggan, dengan tingkat preposisi sebesar $10 \%$. Berikut perhitungan jumlah sampel dengan menggunakan rumus slovin :

$$
\begin{aligned}
n & =\frac{5000}{1+5000(0,10)}_{\text {responden }} \\
& =98,039(100)
\end{aligned}
$$

Dari perhitungan diatas, sampel yang akan digunakan berjumlah 98,03 atau dibulatkan menjadi 100 responden. Dengan karakteristik responden yakni: 1) Konsumen yang sudah berkunjung serta sudah melakukan pembelian produk pada menu Rustic Market Surabaya minimal 1 kali, 2) Responden rentang usia antara 16 - 40 tahun, karena responden berusia tersebut dianggap mampu memahami isi angket yang diberikan dan secara pribadi maupun ekonomi sehingga mempunyai keinginan dalam pemenuhan kebutuhan dengan cara melakukan pembelian. Berikut rancangan penelitian yang akan dilakukan:

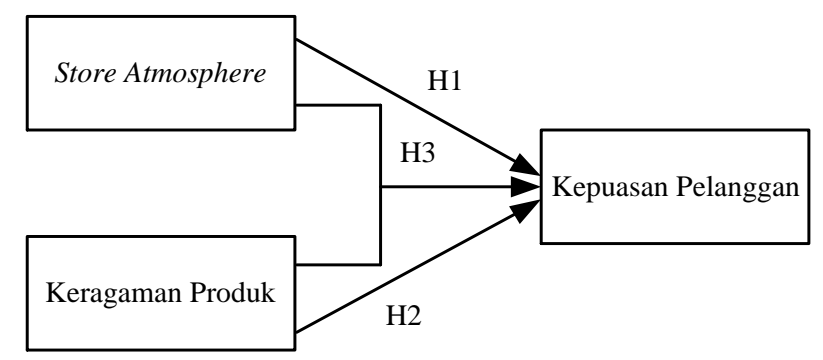

Gambar 1. Rancangan Penelitian

(Sumber: Diolah Peneliti, 2021)

Teknik pengambilan sampel dalam penelitian berikut adalah teknik purposive sampling merupakan teknik penentuan sampel melalui pertimbangan yang telah ditentukan. Dengan skala likert 1-5 antara lain sangat tidak setuju, tidak setuju, netral, setuju, sangat setuju, dengan jumlah 22 item pernyataan. Setelah data terkumpul kemudian melakukan teknik analisis data. Penelitian ini menggunakan teknik analisis berupa uji asumsi klasik yang terdapat didalamnya uji multikolinieritas, normalitas,dan heteroskedastisitas sedangkan uji hipotesisnya menggunakan teknik analisis berganda yang didalamnya meliputi analisis koefisien determinasi $\left(\mathrm{R}^{2}\right.$ ), uji parsial (uji T) dan uji Simultan (uji F). Teknik analisis data pada penelitian berikut analisis regresi linier berganda melalui bantuan SPSS versi 25.Teknik pengumpulan data pada penelitian ini menggunakan penyebaran kuesioner online melalui Google Form dengan subyek pelanggan Coffee shop Rustic Market Surabaya dimana responden akan mengisi angket pada linkhttps://rebrand.ly/kepuasanpelanggan-rusticmarket

\section{HASIL DAN PEMBAHASAN}

Hasil dari penelitian diperoleh melalui penyebaran angket berjumlah 100 responden dan penyebaran angket yang telah diisi oleh responden ditampilkan hasil sebagai berikut: 
Tabel 1. Karakteristik responden

\begin{tabular}{lll}
\hline Karakteristik & Jumlah & Presentase \\
\hline Usia & & \\
$16-25$ & 91 & $90,1 \%$ \\
26-35 & 5 & $5 \%$ \\
$>$ 35 Tahun & 5 & $5 \%$ \\
Jenis Kelamin & & \\
$\quad$ Perempuan & 70 & $69,3 \%$ \\
$\quad$ Laki-laki & 31 & $30,7 \%$ \\
Pekerjaan & & \\
Pelajar & 14 & $13,9 \%$ \\
Mahasiswa & 56 & $55,4 \%$ \\
Pegawai/Karyawan & 23 & $22,8 \%$ \\
Lainnya & 8 & $7,9 \%$ \\
\hline
\end{tabular}

(Sumber: Diolah peneliti, 2021)

Berdasarkan tabel diatas menunjukkan bahwa karakteristik responden yang paling dominan melakukan pembelian di Coffee shop Rustic Market Surabaya adalah responden yang rentang usianya16-25 tahun, menunjukkan jikaCoffee shop Rustic Market Surabaya menjadi tempat berkumpulnya remaja dewasa.

Karakteristik responden yang berkunjung di Rustic Market Surabaya lebih banyak yang berjenis kelamin wanita dengan persentase 69,3\%. Hal tersebut membuktikan bahwa pelanggan perempuan lebih sering datang dan melakukan pembelian diRustic Market Surabaya dibandingkan konsumen laki-laki. Sebab sebagian besar waktu perempuan digunakan seperti bercerita, bertemu dengan rekan atau bersantai.

Karakteristik responden yang berkunjung dan melakukan pembelian di Coffee shop Rustic Market Surabaya dominan lebih banyak mahasiswa dengan persentase 55,4\%. Dengan menunjukkan pelanggan diRustic Market Surabaya adalah orang yang menyukai suasana baru artinya mahasiswa menyukai tempat yang menyediakan view serta fasilitas kekinian guna tempat berbincang, mengerjakan tugas dan kepentingan lainnya.

Tabel 2. Uji Normalitas

\begin{tabular}{lc}
\hline \hline $\mathrm{N}$ & $\begin{array}{c}\text { Unstandardized } \\
\text { Residual }\end{array}$ \\
\hline \hline Test Statistic & 0,079 \\
\hline \hline Asymp, SIg, (2-tailed) & $0,131^{\mathrm{c}}$ \\
\hline
\end{tabular}

(Sumber: Diolah peneliti, 2021)

Pada tabel berikut dapat dilihat terdapat hasil uji normalitas pada penelitian ini nilai signifikasi dari unstandardized residual yakni 0,131. Artinya yang dimana nilai residual lebih besar dari 0,05 sehingga nilai residual dinyatakan terdistribusi normal dan data dikatakan normal.

Tabel 3. Uji Multikolinieritas

\begin{tabular}{ccc}
\hline $\begin{array}{c}\text { Model } \\
\text { (constant) }\end{array}$ & $\begin{array}{c}\text { Collinearity } \\
\text { Tolerance }\end{array}$ & $\begin{array}{c}\text { Statistics } \\
\text { VIF }\end{array}$ \\
\hline \hline Store Atmosphere & 0,521 & 1,921 \\
\hline \hline Keragaman Produk & 0,521 & 1,921 \\
\hline
\end{tabular}

(Sumber : Diolah peneliti, 2021) 
Uji multikolinieritas pada penelitian ini dilakukan dengan menampilkan nilai tolerance dan nilai variance inflation factor (VIF) melalui aplikasi SPSS 25.0. Dapat diketahui pada tabel di atas bahwa hasil dari uji multikolinieritas pada aplikasi SPSS 25.0 dapat dilihat bahwasannya seluruh variabel bebas $(\mathrm{X})$ penelitian berikut yakniStore Atmosphere $\left(\mathrm{X}_{1}\right)$ dan Keragaman Produk $\left(\mathrm{X}_{2}\right)$ mempunyai toleransi 0,521 >0,1 sehinggabisa dinyatakan tidak terjadinya multikolinieritas dan nilai VIF dari kedua variabel bebas yaitu 1,921 atau artinya< 10 yang menunjukkan tidak adanya gejala multikolinieritas. Oleh karena itu disimpulkan tidak adanya gejala multikolinieritas pada model regresi.

Tabel 4. Uji Heteroskesdastisitas

\begin{tabular}{lc}
\hline \hline & Sig \\
\hline \hline Store Atmosphere & 0,071 \\
\hline \hline Keragaman Produk & 0,996 \\
\hline
\end{tabular}

(Sumber: Diolah peneliti, 2021)

Berdasarkan pada Uji SPSS 25.0 dapat ditunjukkan jika titik-titik menyebar secara acak serta tidak adanya terbentuk pola dan dalam uji Glejserpada penelitian ini menjelaskan bahwa variabel store atmosphere mempunyai nilai signifikansi sebesar 0,071 dan pada variabel keragaman produk menampilkan nilai signifikansi 0,996. Maka dapat ditarik kesimpulan bahwa pada nilai signifikansi kedua variabel bebas berikut lebih besar dari 0,05 serta dapat ditarik kesimpulan bahwa dalam hasil uji heteroskedastisitas membuktikan tidak adanya gejala heteroskedastisitas.

Tabel 5. Regresi Linier Berganda

\begin{tabular}{lcccc}
\hline \hline Model & $\begin{array}{c}\text { Unstandardized } \\
\text { Coefficients }\end{array}$ & & $\begin{array}{l}\text { Standardized } \\
\text { Coefficients }\end{array}$ & Sig \\
& $\mathrm{B}$ & Std. Error & Beta & \\
\hline \hline Constant & 3,913 & 2,107 & & 0,066 \\
\hline \hline Store Atmosphere & 0,183 & 0,085 & 0,195 & 0,033 \\
\hline \hline Keragaman Produk & 6,856 & 0,069 & 0,619 & 0,000 \\
\hline
\end{tabular}

(Sumber: Diolah peneliti, 2021)

Dari tabel diatasmenunjukkan bahwa dijelaskan persamaan regresi linier berganda sebagai berikut :

$\mathrm{Y}=3,913+0,183 \mathrm{X}_{1}+0,473 \mathrm{X}_{2}+\mathrm{e}$

Keterangan:

$\mathrm{X}_{1}=$ Store Atmosphere

$\mathrm{X}_{2}=$ Keragaman Produk

$\mathrm{Y}=$ Kepuasan Pelanggan

Berdasarkan pemaparan persamaan regresi linier, bahwa dapat dikatakan beberapa pernyataan berikut ini :

1) Konstanta 3,913 menunjukkan nilai positif (+) sehingga diartikan bahwa variabel bebas yakniStore Atmosphere dan Keragaman Produk (nilai $\mathrm{X}_{1}$ dan $\mathrm{X}_{2}$ adalah 0), maka nilai variabel kepuasan pelanggan sebesar 3,913. Artinya apabila $X_{1}$ dan $X_{2}$ tidak mengalami adanya perubahan maka akan tetap adanya kepuasan pelanggan disebabkan pengaruh dari variabel di luar penelitian ini. 
2) Nilai koefisien regresi pada variabel Store Atmosphere $\left(\mathrm{X}_{1}\right)$ yakni 0,183 bernilai positif (+) artinya jika Store Atmosphere menunjukkan kenaikan satu-satuan, oleh karena itu nilai kepuasan pelanggan nantinya meningkat sebesar 18,3\%. Sedangkan pada nilai signifikansi yaitu 0,33 yang berartiStore Atmosphere bernilai signifikan ditunjukkan dari besar sampel mewakili kebenaran dari jumlah populasi.

3) Nilai koefisien regresi pada variabel Keragaman Produk $\left(X_{2}\right)$ yaitu 0,473 bernilai positif (+) yang artinya bahwa nilai harga kenaikan satu-satuan, oleh karena itu nilai kepuasan pelanggan mengalami peningkatan yakni $47,3 \%$. Sedangkan diketahui nilai signifikansi sebesar 0,000 yang menunjukkan jika keragaman produk memiliki nilai signifikan yang artinyabesar sampel mewakili kebenaran dari jumlah populasi.

\begin{tabular}{|c|c|c|}
\hline \multicolumn{3}{|c|}{ Tabel 6. Hasil Uji t (Uji Parsial) } \\
\hline Model & $\overline{\mathrm{T}}$ & Sig. \\
\hline Constant & 1,857 & 0,066 \\
\hline Store Atmosphere & 2,164 & 0,033 \\
\hline
\end{tabular}

Pada nilai $t_{\text {hitung }}$ variabel Store Atmosphere $\left(\mathrm{X}_{1}\right)$ jumlahnya 2,164 dengan P-value sebanyak 0,033 nilainya lebih kecil daripada 0,05 . Maka didapatkan keputusan yakni $\mathrm{H}_{0}$ ditolak dan $\mathrm{H}_{1}$ diterima artinya Store Atmosphere $\left(\mathrm{X}_{1}\right)$ adanya pengaruhpositif dan signifikan secara parsial terhadap Kepuasan Pelanggan (Y), sehingga hipotesis pertama dapat diterima.

Sehingga dapat dikatakan terdapat pengaruh antara store atmosphere terhadap kepuasan pelanggan di Coffee shop Rustic Market Surabaya. Hal ini sesuai dengan fenomena yang dijabarkan pada latar belakang penelitian, yakni satu di antara beberapa faktor yang membuat konsumen dapat mendapatkan kepuasan pelanggan dikarenakan terdapat store atmosphere terhadap kepuasan pelanggan yang baik. Suasana toko yakni desain lingkungan atau ciri khas toko dari perpaduan kombinasi mulai dari komunikasi visual, musik, pencahayaan, warna serta aroma merangsang tanggapan emosional pelanggan dapat mempengaruhi kepuasan pelanggan saat di cafe tersebut yang semuanya memiliki tujuan untuk memberikan pengaruh pada persepsi pelanggan.

Pada kuesioner berikut telah disebarkan kepada responden dapat disimpulkan indikator Store Atmosphere di Coffee shop Rustic Market Surabaya adalah General Exterior,Store Layout, General Interior dan Interior Display. Hasil penelitian yang dilakukan menjelaskan bahwa Store Atmosphere bagian penting dalam strategi pemasaran sebagai daya tarik perhatian pembeli agar merasa puas berada di cafe tersebut. Dapat dilihat dari Store Atmosphere di Coffee shop Rustic Market Surabaya bahwa terdapat banyak tempat duduk, tersedia spot tempat duduk dengan tema dekorasi rustic dihiasi dengan properti pedesaan dengan pencahayaan warna hangat cocok untuk dijadikan latar berfoto yang instagrammable. Terdapat suara alunan musik yang memberikan kesan relax, pengharum ruangan dan kemudahan akses masuk ke Rustic Market Surabaya. Penataan meja dan kursi yang nyaman, penempatan kasir dan pemesanan menu yang memberikan kemudahan.

Berdasarkan hasil penelitian berikut sejalan dengan hasil penelitian yang telah dilaksanakan(Rofi'ah, 2020) bahwa menunjukkan pengaruh positif dansignifikan pada variabel store atmosphere terhadap kepuasan pelanggan. Hal berikut selaras dengan penelitian yang dilaksanakan oleh (Hidayat, 2020) menunjukkanstore atmosphere memiliki pengaruh signifikan. Hasil kajian dari penelitian yang telah dilaksanakan oleh beberapa peneliti dapat dikatakan bahwa variabel store atmospherememiliki pengaruh terhadap kepuasan pelanggan. 


\begin{tabular}{ccc}
\hline R & R square & $\begin{array}{c}\text { Adjusted R } \\
\text { Square }\end{array}$ \\
\hline \hline $0,767^{\mathbf{a}}$ & 0,589 & 0,580 \\
\hline
\end{tabular}

Berdasarkan hasil penelitian tersebut serta didukung oleh penelitian terdahulu, sehingga penelitian berikut dapat ditarik kesimpulan bahwasannya $\mathrm{H}_{1}$ diterima yakni variabel store atmosphereberpengaruh terhadap kepuasan pelanggan di Coffee shop Rustic Market Surabaya.

\section{Pengaruh Keragaman Produk $\left(\mathrm{X}_{2}\right)$ terhadap Kepuasan Pelanggan $(\mathrm{Y})$}

\begin{tabular}{lcc}
\multicolumn{3}{c}{ Tabel 7. Hasil Uji t (Uji Parsial) } \\
\hline \hline Model & T & Sig. \\
\hline \hline Constant & 1,857 & 0,066 \\
\hline \hline $\begin{array}{l}\text { Keragaman } \\
\text { Produk }\end{array}$ & 6,856 & 0,000 \\
\hline
\end{tabular}

\section{(Sumber: Diolah peneliti, 2021)}

Pada nilai $t_{\text {hitung }}$ variabel Keragaman Produk $\left(\mathrm{X}_{2}\right)$ jumlahnya 6,856 dengan P-value sebanyak 0,000 artinya nilai lebih kecil daripada 0,05 . Maka didapatkan keputusan yakni $\mathrm{H}_{0}$ ditolak dan $\mathrm{H}_{2}$ diterima artinya Keragaman Produk $\left(\mathrm{X}_{2}\right)$ terdapat pengaruhpositif dan signifikan secara parsial terhadap Kepuasan Pelanggan (Y), sehingga menunjukkan hipotesis kedua dapat diterima.

Pada hasil uji $\mathrm{T}$, diperoleh sebesar 6,856 secara parsial diperoleh nilai signifikansi yang baik yakni 0,000. Artinya variabel keragaman produk berpengaruh terhadap kepuasan pelanggan. Hal ini memperlihatkan bahwa variabel keragaman produk berbanding lurus. Jika keragaman produk ditingkatkan, maka kepuasan pelanggan di Coffee shop Rustic Market Surabaya mengalami peningkatan.

Menurut (Safitri et al., 2017) Keragaman produk adalah keputusan mengenai variasi atau keragaman dari setiap produk dan kualitas produk, selain itu keragaman produk memperlihatkan lebih beragam pilihan tersedia, kemungkinan terpenuhinya kebutuhan juga lebih besar maka pelanggan secara tidak langsung efektif dan efisien dalam mencari produk yang diinginkan. Di Coffee shop Rustic Market Surabaya sendiri juga memberikan perhatian akan keragaman produk pada varian menunya oleh seluruh pelanggan. Hal ini dapat dilihat dari konsep menu yang ditawarkan oleh Rustic Market kepada pelanggan dengan menawarkan menu Western dan berbagai varian menu makanan, minuman dan es cream gelato. Pilihan rasa pun terdapat banyak varian rasa, ukuran dan sebagainya.

DiRustic Market Surabaya, keragaman produk dapat dilihat dari 1) Tersedia beraneka macam rasa dan jenis makanan dan minuman ala western. 2) Merupakan cafe yang terkenal di kalangan remaja dewasa. 3) Pilihan ukuran menu minuman kopi yang ditawarkan bervariasi. 4) Memiliki kelengkapan menu yang selalu tersedia. 5) Kualitas menu makanan, minuman dan es cream gelato yang ditawarkan sesuai keinginan dan terjamin kualitasnya. Keragaman produk mempunyai pengaruh positif pada kepuasan pelanggan, berarti jika menu yang dijual semakin beragam maka akan meningkatkan kepuasan pelanggan Coffee shop Rustic Market Surabaya.

Diketahui hasil penelitian berikut selaras dengan penelitian yang telah dilaksanakan(Safitri et al., 2017) memaparkan bahwa keragaman produk terdapat pengaruh 
positif dan signifikan terhadap kepuasan pelanggan. Begitu juga selaras dengan penelitian (Nainggolan et al., 2016) membuktikan bahwa adanya pengaruh signifikan keragaman produk terhadap kepuasan pelanggan. Hasil kajian dari penelitian yang telah dilaksanakan oleh beberapa peneliti dapat dikatakan bahwa variabel keragaman produk adanya pengaruh terhadap kepuasan pelanggan di Coffee shop Rustic Market Surabaya.

Berdasarkan hasil penelitian tersebut juga didukung dari penelitian terdahulu, jadi pada penelitian ini dapat ditarik kesimpulan jika $\mathrm{H}_{2}$ diterima yaitu keragaman produk berpengaruh terhadap kepuasan pelanggan di Coffee shop Rustic Market Surabaya.

\section{Pengaruh Store Atmosphere $\left(\mathrm{X}_{1}\right)$ dan Keragaman Produk $\left(\mathrm{X}_{2}\right)$ terhadap Kepuasan Pelanggan (Y)}

Tabel 8. Hasil Uji F

\begin{tabular}{lcc}
\hline \hline Model & $\boldsymbol{F}_{\text {hitumg }}$ & Sig. \\
\hline \hline Regression & 69,367 & $0,000^{\mathrm{b}}$ \\
\hline \hline
\end{tabular}

(Sumber: Diolah peneliti, 2021)

Berpedoman tabel hasil uji F memperlihatkan nilai $F_{\text {hitung }}$ sejumlah 69,367 dengan P-value sebanyak 0,000.Artinya $\mathrm{P}$-valuelebih kecil daripada 0,05 sehingga $\mathrm{H}_{3}$ diterima yang dimana secara simultan variabel lebih kecil dari 0,05 makavariabel Store Atmosphere dan keragaman produk memiliki pengaruhterhadap kepuasan pelanggan, dapat ditarik kesimpulan hipotesis ketiga atau $\mathrm{H}_{3}$ diterima.

Dari penelitian berikut analisis uji $\mathrm{F}$ menghasilkan kesimpulan bahwasanya kedua variabel bebas (variabel Store atmosphere dan keragaman produk berkaitan dengan kepuasan pelanggan). Mengacu pada hasil yang telah diperoleh bahwa semakin tinggi kepuasan pelanggan dimanaStore atmosphere dan keragaman produk yang ditawarkan sesuai minat dan harapan konsumen di Coffee shop Rustic Market Surabaya.

Kepuasan Pelanggan memiliki tiga indikator pengukuran yakni, Kesesuaian harapan, kesediaan merekomendasi serta minat berkunjung kembali. Kepuasan pelanggan di Coffee shop Rustic Market Surabaya dapat ditunjukkan dari 1) Puas dengan cita rasa menu makanan, minuman dan dessert ice cream gelato yang disediakan serta kenyamanan, keamanan, dan kebersihan cafe, 2) Akan berkunjung kembali dan memesan kembali menu yang tersedia, dan 3) Merekomendasi pada orang lain untuk berkunjung serta memberikan persuasi positif pada orang lain tentang Coffee shop Rustic Market Surabaya.

Berdasarkan hasil penelitian tersebut juga didukung dari penelitian terdahulu, maka pada penelitian ini dapat ditarik kesimpulan jika $\mathrm{H}_{1}$ diterima yakni store atmosphereadanya pengaruh terhadap kepuasan pelanggan di Coffee shopRustic Market Surabaya. Berdasarkan dari data hasil penelitian yang didukung dari teori dan penelitian terdahulu dapat disimpulkan jika $\mathrm{H}_{2}$ diterima ialah keragaman produk serta store atmosphere berpengaruh pada kepuasan pelanggan di Coffee shop Rustic Market Surabaya.

\begin{tabular}{cc}
\multicolumn{2}{c}{ Tabel 9. Hasil Koefisien Determinasi $\mathbf{R}^{\mathbf{2}}$} \\
\hline \hline R Square & \multicolumn{1}{c}{ Adjusted R Square } \\
\hline \hline 0,589 & 0,580
\end{tabular}

(Sumber: Diolah Peneliti, 2021)

Berdasar dari hasil analisis SPSS 25.0 model summary diketahui besarnya Adjusted R Square yakni0,580 atau 58\% sehingga variabel Store atmosphere dan keragaman produk memiliki 
kontribusi untuk menjelaskan variabel kepuasan pelanggan sebesar 58\% dan selisihnya sebesar $42 \%$ digambarkan dari variabel-variabel di luar penelitian ini.

\section{KESIMPULAN}

Berdasarkan kesimpulan pada pembahasan penelitian berikut menunjukkanhasil analisis data terkait Pengaruh Store Atmosphere dan Keragaman Produk terhadap Kepuasan Pelanggan di Coffee shop Rustic Market Surabaya, dapat ditarik kesimpulan yakni sebagai berikut:

1. Store Atmosphere adanya pengaruh signifikan terhadap kepuasan pelanggan diCoffee shopRustic Market Surabaya.

2. Keragaman Produk adanya pengaruh signifikan terhadap kepuasan pelanggandi Coffee shopRustic Market Surabaya.

3. Store atmosphere dan keragaman produk memiliki pengaruh signifikan terhadap kepuasan pelanggan di Coffee shop Rustic Market Surabaya.

\section{DAFTAR PUSTAKA}

Arinda, F., Soetjipto, B. E., \& Hermawan, A. (2018). The Effect of Product Quality, Brand Image, and Menu Variety on Customer' s Loyalty Through Customer' s Satisfaction as An Intervening Variable. European Journal of Business and Management, 10(11), 175184.https://core.ac.uk/download/pdf/234628361.pdf

Hidayat, M. S. (2020). Pengaruh Harga dan Store Atmosphere terhadap Kepuasan Konsumen pada Café Dreamblack Coffee Mojokerto. Bisman (Bisnis Dan Manajemen): The Journal of Business and Management, 3(2), 173-186. https://doi.org/10.37112/bisman.v3i2.796

Nainggolan, L., Pradhanawati, A., \& Hidayat, W. (2016). Pengaruh Kualitas Pelayanan, Keragaman Produk Dan Lokasi Terhadap Kepuasan Pelanggan (Studi Kasus Pada Pelanggan Stove Syndicate Cafe Di Semarang). Jurnal Ilmu Administrasi Bisnis, 5(4), 531-541.

Novendra H, D., Verinita, \& Masykura, I. (2019). The Effect of Store Atmosphere on Revisit Intention that is in Mediation by Customer Satisfaction ( Survey on Padang Bioderm Clinic Consumer ). International Journal of Innovative Science and Research Technology, 4(4).

Purwadi, P., Devitasari, B., \& Caisar Darma, D. (2020). Store Atmosphere, SERVQUAL and Consumer Loyalty: Case Study of Excelso Coffee Shop. SEISENSE Journal of Management, 3(4), 21-30. https://doi.org/10.33215/sjom.v3i4.385

Putri, L. H., Kumadji, S., \& Kusumawati, A. (2014). PENGARUH STORE ATMOSPHERE TERHADAP KEPUTUSAN PEMBELIAN DAN KEPUASAN PELANGGAN (Studi pada Monopoli Cafe and Resto Soekarno Hatta Malang). Jurnal Administrasi Bisnis S1 Universitas Brawijaya, 15(2), 84724.

Rofi'ah, M. (2020). Pengaruh Store Atmosphere dan Kualitas Produk Terhadap Kepuasan Konsumen Navila Cafe. Journal of Business and Innovation Management, 2(2), 233245.

Rohmawati, Z. (2018). Kualitas, Harga Dan Keragaman Produk Terhadap Loyalitas Pelanggan. Jurnal Riset Entrepreneurship, 1(2), 19.https://doi.org/10.30587/jre.v1i2.418

Safitri, R. S. N. I., Utami, S. S., \& Sunarso. (2017). Analisis pengaruh store atmosphere , harga, kualitas pelayanan, dan keragaman produk terhadap kepuasan konsumen pada cafe \& resto. Jurnal Ekonomi Dan Kewirausahaan, 17(2), 390-398.

Sari, P. A. (2020). PENGARUH KUALITAS LAYANAN DAN CAFE ATMOSPHERE 
TERHADAP KEPUASAN PELANGGAN (Studi Pada Pelanggan Tipo Cafe Surabaya). Jurnal Pendidikan Tata Niaga (JPTN), 8(2).

Sulaeman, M. M. (2020). Sosialisasi Kewirausahaan dalam Upaya Peningkatan UMKM Desa Palangan Kecamatan Karangbinangun Kabupaten Lamongan. Jurnal Abdimas Berdaya: Jurnal Pembelajaran, Pemberdayaan dan Pengabdian Masyarakat,2 (01), 1622.

Syairozi, M. I. (2021). ANALISIS KEMISKINAN DI SEKTOR PERTANIAN (Studi Kasus Komoditas Padi di Kabupaten Malang). Media Ekonomi, 28(2), 113-128.

Wuyanti, L., \& Mulyaningsih, R. (2018). The Effect Of Shop Atmosphere, Product Diversity, Taste Of Taste, Price And Lifestyle On Consumer Purchase Decision (Studies in Cafe Happy Ice Cream Sukarame, Bandar Lampung). Jurnal Riset Akuntansi Dan Manjemen, Vol. 7, No. 1, Juni 2018, 7(1), 56-64. 